\title{
NTPDase and acetylcholinesterase activities in silver catfish, Rhamdia quelen (Quoy \& Gaimard, 1824) (Heptapteridae) exposed to interaction of oxygen and ammonia levels
}

\author{
Rosilene Rodrigues Kaizer, Vania Lúcia Loro, Maria Rosa Chitolina Schetinger, \\ Vera Maria Morsch, Luciane Almeri Tabaldi, Cíntia Saydelles da Rosa, \\ Luciano de Oliveira Garcia, Alexssandro G. Becker and Bernardo Baldisserotto
}

The effects of various levels of oxygen saturation and ammonia concentration on NTPDase (ecto-nucleoside triphosphate diphosphohydrolase, E.C. 3.6.1.5) and acetylcholinesterase (AChE, E.C. 3.1.1.7) activities in whole brain of teleost fish (Rhamdia quelen) were investigated. The fish were exposed to one of two different dissolved oxygen levels, including high oxygen (6.5 mg. $\mathrm{L}^{-1}$ ) or low oxygen (3.5 mg. $\left.\mathrm{L}^{-1}\right)$, and one of two different ammonia levels, including high ammonia (0.1 mg. $\left.\mathrm{L}^{-1}\right)$ or low ammonia (0.03 mg. $\left.\mathrm{L}^{-1}\right)$ levels. The four experimental groups included the following (A) control, or high dissolved oxygen plus low $\mathrm{NH}_{3}$; (B) low dissolved oxygen plus low $\mathrm{NH}_{3}$; (C) high dissolved oxygen plus high $\mathrm{NH}_{3}$; (D) low dissolved oxygen plus high $\mathrm{NH}_{3}$. We found that enzyme activities were altered after $24 \mathrm{~h}$ exposure in groups $\mathrm{C}$ and $\mathrm{D}$. ATP and ADP hydrolysis in whole brain of fish was enhanced in group D after $24 \mathrm{~h}$ exposure by $100 \%$ and $119 \%$, respectively, compared to the control group. After $24 \mathrm{~h}$ exposure, AChE activity presented an increase of 34\% and 39\% in groups C and D, respectively, when compared to the control group. These results are consistent with the hypothesis that low oxygen levels increase ammonia toxicity. Moreover, the hypoxic events may increase blood flow by hypoxia increasing NTPDase activity, thus producing adenosine, a potent vasodilator.

No presente estudo, avaliou-se o efeito de diferentes níveis de saturação de oxigênio e amônia sobre a atividade das enzimas NTPDase (ecto-nucleosídeo trifosfato difosfohidrolase, E.C. 3.6.1.5) e acetilcolinesterase (AChE, E.C. 3.1.1.7) em encéfalo total de jundiás (Rhamdia quelen). Os peixes foram expostos a diferentes níveis de oxigênio dissolvido e amônia, níveis altos de oxigênio (6,5 mg/L) ou baixos de oxigênio (3,5 mg/L), e níveis altos de amônia (0,1 mg/L) ou baixos de amônia (0,03 mg/L). Os peixes foram divididos em quatro diferentes grupos: (A) controle ou alto nível de oxigênio dissolvido mais baixo nível de $\mathrm{NH}_{3}$; (B) baixo nível de oxigênio dissolvido mais baixo nível de $\mathrm{NH}_{3}$; (C) alto nível de oxigênio dissolvido mais alto nível de amônia; (D) baixo nível de oxigênio dissolvido mais alto nível de $\mathrm{NH}_{-3}$. As atividades de ambas as enzimas nos grupos $\mathrm{C}$ e $\mathrm{D}$ somente foram alteradas após 24 horas de exposição. A hidrólise do ATP e ADP em encéfalo total de jundiás foi aumentada após 24h de exposição para $104 \%$ e $155 \%$ no grupo D quando comparado ao grupo controle, respectivamente. A atividade da AChE apresentou após 24h de exposição um aumento de 37\% no grupo C e 27\% no grupo D, ambos comparados ao grupo controle. Os resultados obtidos corroboram com a hipótese que baixos níveis de saturação de oxigênio aumentam a toxicidade da amônia. Além disso, os eventos de hipóxia podem aumentar o fluxo sanguíneo, e este evento aumenta a atividade da NTPDase produzindo adenosina, um potente vasodilatador.

Key words: Fish, ATP, ADP, AChE.

Departamento de Química, Centro de Ciências Naturais e Exatas, Universidade Federal de Santa Maria, Campus Universitário, Camobi, 97105-900 Santa Maria, RS, Brazil.vanial@smail.ufsm.br (VLL) 


\section{Introduction}

The biological response of an aquatic organism to pollutants frequently involves changes at cellular and biochemical levels, leading to changes in the structure and function of the cells, tissues, and behavior of the organism (Parvez \& Raisuddin, 2005). Ammonia is a common aquatic pollutant and is toxic to fish (Miron et al., 2008). The main source of endogenous ammonia in fish is direct deamination of amino acids (Le-Ruyet et al., 1997). In fish, the endogenous ammonia concentration can also be increased by elevated concentrations of exogenous ammonia (Foss et al., 2007). In addition to un-ionized ammonia, other critical parameters determining water quality include dissolved oxygen, nitrite and carbon dioxide levels (Foss et al., 2007). While ammonia alone is highly toxic, ammonia that has interacted with low oxygen levels becomes more toxic (Wajsbrot et al., 1991; Foss et al., 2007). In fish, high ammonia levels cause hyperventilation (McKenzie et al., 1993), hyper-excitability, coma, convulsions and, finally, death (Wee et al., 2007). However, it has been suggested that oxygen levels above normal saturation might reduce ammonia toxicity (Colt et al., 1991).

The toxicity of ammonia to aquatic organisms has been attributed mainly to the un-ionized form $\left(\mathrm{NH}_{3}\right)$, while the ionized form $\left(\mathrm{NH}_{4}^{+}\right)$is considered less toxic (Thurston et al., 1984; Wood, 2001). In fact, biological membranes of freshwater teleosts are very permeable to un-ionized ammonia $\left(\mathrm{NH}_{3}\right)$ but not to $\mathrm{NH}_{4}^{+}$(Alabaster \& Lloyd, 1980). Moreover, it has been reported that the un-ionized form of ammonia freely crosses the blood-brain barrier by diffusion (Cooper et al., 1979). As a result, the increase in ammonia levels leads to severe central nervous system (CNS) dysfunctions in various organisms from fish to mammals (Viseck, 1968; Smart, 1976; Cooper \& Plum, 1987; Butterworth, 1998; Atwood et al., 2000; Felipo \& Butterworth, 2002). Many electrophysiological and biochemical mechanisms have been proposed to underlie the deleterious effects of ammonia on the CNS (Ronan et al., 2007).

In addition, ammonia plays a role in several biochemical processes and in enzymatic reactions, so alterations in ammonia levels can dramatically impact these processes. For example, increases in ammonia levels interfere with brain energy metabolism (Foss et al., 2007). The primary intracellular energy source is ATP, which also acts as an extracellular signaling molecule (Fields \& Burnstock, 2006). Indeed, ATP is considered to be one of the most important neurotransmitters in the purinergic system (Fredholm, 1995). Purinergic signaling is responsible for modulating many of the signaling and biosynthetic processes in which extracellular nucleotides are involved, including vascular homeostasis, cell size maintenance, neuronal signaling, immune function, and protein and lipid modification (Brake \& Julius, 1996; Burnstock, 1998; Gayle et al., 1998; Enjyoji et al., 1999; Marcus et al., 2003; Schweibert \& Zsembery, 2003). Moreover, the NTPDase family, composed of the eight members NTPDase 1 to 8 , is involved in controlling nucleotide and nucleoside concentrations, acting to regulate purinergic neurotransmission
(Rico et al., 2008). Four members of the NTPDase family are typical cell surface-located enzymes with an extracellularly facing catalytic site (NTPDase1, 2, 3, 8). Thus, these nucleotidases constitute a highly refined system for regulating nucleotide-mediated signaling through ATP and/or ADP hydrolysis at the surface of many cells types (Robson et al., 2006; Rico et al., 2008). Additionally, following hydrolysis of ATP to AMP, AMP is dephosphorylated to adenosine by 5'nucleotidase (Zimmermann, 1992). Adenosine is a good candidate for a metabolic signal because it is produced rapidly in response to decreasing oxygen and acts on specific receptors $\left(A_{1}, A_{2 A}, A_{2 B}\right.$ and $A_{3}$ ) (Fredholm et al., 2001). Functionally, adenosine is a potent vasomodulator in mammalian and non-mammalian vertebrates, producing vasodilation in systemic, coronary and cerebral vessels (Lutz \& Reiners, 1997; Mubagwa \& Flameng, 2001).

ATP and the neurotransmitter acetylcholine (ACh) are coreleased and are inactivated enzymatically in the synaptic cleft by ectonucleotidases and cholinesterases, respectively (Gonçalves \& Silva, 2007). ACh is critical to CNS function. Among the functions of ACh, it is involved in learning, memory, cortical organization of movement and control of cerebral blood flow (Schetinger et al., 1999). ATP acts as a cotransmitter and a modulator of cholinergic transmission, regulating ACh release by signaling through $\mathrm{P} 2 \mathrm{X}$ and $\mathrm{P} 2 \mathrm{Y}$ receptors (Cunha \& Ribeiro, 2000; Dahm et al., 2006). The enzyme acetylcholinesterase (AChE, E.C. 3.1.1.7) is responsible for the hydrolysis of the ACh to choline and acetate in cholinergic synapses. In fish, AChE is enriched in brain and muscle tissues. Disturbances in AChE activity can affect locomotion and equilibrium in aquatic organisms and may impair feeding, escape, and reproductive behavior (Habig \& Di Giulio, 1991; Saglio \& Trijasse, 1998; Bretaud et al., 2000). The majority of information on brain and muscle AChE comes from inhibition of the enzyme, mainly through pesticide toxicity (Fernandez-Vega et al., 2002). When the enzyme is inhibited, ACh is not hydrolyzed in nerve synapses and neuromuscular junctions, causing build-up of ACh at these sites and leading to overstimulation of brain and muscular tissue (Roex et al., 2003). Because these previous studies were based on enzyme inhibition, the details of enzyme activation are little known in fish, although AChE activation likely affects ACh concentration in the synaptic cleft. Recently, reports have indicated that several pesticide classes, such as isooxazolidinone, quinoline, dichloropropionanilide and sulfonylurea enhance AChE activity (Miron et al., 2005; Moraes et al., 2007).

In this study, we studied silver catfish, Rhamdia quelen (Quoy \& Gaimard, 1824, Siluriformes, Heptapteridae), because it is a native freshwater species of economical importance in southern Brazil due to its ability to survive cold winters and grow in the summer (Barcellos et al., 2004). We aimed to determine whether the interaction between two factors, oxygen saturation and ammonia levels, can alter the purinergic and cholinergic systems. To do so, we evaluated NTPDase and AChE activities in whole brain of silver catfish exposed to various oxygen and ammonia levels. 


\section{Material and Methods}

\section{Animals and treatments}

Juvenile silver catfish $(156.1 \pm 0.2 \mathrm{~g}, 28.2 \pm 0.3 \mathrm{~cm})$ obtained from a local fish farm were maintained in continuously aerated 250-L tanks for at least one week prior to experiments. Fish were maintained in darkness $24 \mathrm{~h}$ per day (except during feeding and cleaning of the tanks) as dark environments are favorable to silver catfish (Piaia et al., 1999). They were fed once a day with commercial feed for juvenile fish (Supra, $42 \%$ CP, Alisul Alimentos S.A., Carazinho, Brazil) until apparent satiety up to $24 \mathrm{~h}$ before the experiment. The methodology used in this experiment was approved by the Ethical and Animal Welfare Committee of the Universidade Federal de Santa Maria, protocol number: 073/2007.

Following acclimation, fish were separated into twelve 250$\mathrm{L}$ tanks, yielding four treatments with three replicates each ( $\mathrm{n}=7$ per tank). The four treatments included (A) control or high dissolved oxygen $\left(6.5 \pm 0.12 \mathrm{mg} . \mathrm{L}^{-1}\right)+$ low $\mathrm{NH}_{3}(0.03 \pm$ $\left.0.01 \mathrm{mg} . \mathrm{L}^{-1}\right)$, (B) low dissolved oxygen $\left(3.5 \pm 0.18 \mathrm{mg} . \mathrm{L}^{-1}\right)+$ low $\mathrm{NH}_{3}\left(0.03 \pm 0.01 \mathrm{mg} . \mathrm{L}^{-1}\right)$, (C) high dissolved oxygen (6.5 \pm $\left.0.10 \mathrm{mg} . \mathrm{L}^{-1}\right)+$ high $\mathrm{NH}_{3}\left(0.1 \pm 0.02 \mathrm{mg} . \mathrm{L}^{-1}\right)$, and (D) low dissolved oxygen $\left(3.5 \pm 0.13\right.$ mg. $\left.L^{-1}\right)+$ high $\mathrm{NH}_{3}\left(0.1 \pm 0.019 \mathrm{mg} . \mathrm{L}^{-1}\right)$. The high $\mathrm{NH}_{3}$ and low dissolved oxygen values chosen are sublethal values that were previously shown to affect silver catfish growth and survival (Braun et al., 2006; Miron et al., 2008).

Dissolved oxygen level and temperature $\left(24.4 \pm 0.1^{\circ} \mathrm{C}\right)$ were monitored with an oxygen meter (model Y5512, YSI Inc., Yellow Springs, USA). Room temperature was maintained with an air conditioner. The $\mathrm{pH}$ level $(7.38 \pm 0.10)$ was verified with a DMPH-2 pH meter (Digimed, São Paulo, Brazil). Total ammonia level, including $\mathrm{NH}_{3}$ and $\mathrm{NH}_{4}^{+}$, was determined according to Boyd \& Tucker (1992) and $\mathrm{NH}_{3}$ level according to Piper et al. (1982). These parameters were measured every hour throughout the entire acclimation period. Dissolved oxygen levels were maintained through aeration with air and/or nitrogen, while $\mathrm{NH}_{3}$ levels were reached by adding concentrated $\mathrm{NH}_{4} \mathrm{Cl}$ solution. Water hardness $(19.33 \pm 1.33$ mg $\mathrm{CaCO}_{3} \mathrm{~L}^{-1}$ ) was analyzed by the EDTA titrimetric method, and alkalinity (23.97 $\left.\pm 0.6 \mathrm{mg} \mathrm{CaCO}_{3} \mathrm{~L}^{-1}\right)$ and nitrite level (maximum $0.07 \mathrm{mg} \mathrm{L}^{-1}$ ) was measured according to Boyd \& Tucker (1992). These parameters were measured at the beginning and end of the experiment.

Fish were collected at 0,6 and $24 \mathrm{~h}$ after exposure to the experimental conditions and dipped in ice-water slurry $(2.4 \mathrm{~kg}$ ice : $3.6 \mathrm{~L}$ water) for $5 \mathrm{~min}$ to anaesthetize. The whole brain was excised, rapidly placed in a solution of $320 \mathrm{mM}$ sucrose, $0.1 \mathrm{mM}$ EDTA, 5 mM Tris-HCl, $\mathrm{pH} 7.5$ (medium I) at $4^{\circ} \mathrm{C}$ and weighed. Then, tissues were homogenized in 10 volumes of medium I in a motor-driven Teflon-glass homogenizer (15 strokes at $1000 \mathrm{rpm}$ ) and centrifuged for $10 \mathrm{~min}$ at $1000 \mathrm{x} \mathrm{g}$. The supernatant was collected and used in the AChE assay.

\section{Assay of NTPDase activity}

From whole brain, NTPDase activity was determined using a reaction medium containing $5 \mathrm{mM} \mathrm{KCl}, 1.5 \mathrm{mM} \mathrm{CaCl}_{2}, 0.1$
mM EDTA, $10 \mathrm{mM}$ glucose, $225 \mathrm{mM}$ sucrose and $45 \mathrm{mM}$ Tris$\mathrm{HCl}$ buffer, $\mathrm{pH}$ 8.0, in a final volume of $200 \mu \mathrm{L}$, as described in a previous study from our laboratory (Schetinger et al., 2000). First, $20 \mu \mathrm{L}$ of the enzyme preparation (8-10 $\mu$ g of protein) was added to the reaction mixture and pre-incubated for 10 $\min$ at $37^{\circ} \mathrm{C}$. The reaction was initiated by the addition of ATP or ADP to a final concentration of $1.0 \mathrm{mM}$ and proceeded for $20 \mathrm{~min}$. The enzyme activity was expressed in nmol Pi/min.mg of protein.

\section{Acetylcholinesterase assay for whole brain}

AChE activity was assayed in the supernatant of the whole brain (S1). AChE activity was determined according to Ellman et al. (1961), modified by Rocha et al. (1993). The reaction mixture (2 mL final volume) was composed of $100 \mathrm{mM}$

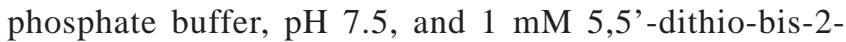
nitrobenzoic acid (DTNB). The method is based on the formation of yellow anion, 4,4'-dithio-bis-2-nitrobenzoic, which was measured by absorbance at $412 \mathrm{~nm}$ during $2 \mathrm{~min}$ at $25^{\circ} \mathrm{C}$. The enzyme (40-50 $\mu$ g of protein) was pre-incubated for $2 \mathrm{~min}$, and the reaction was initiated by adding $0.8 \mathrm{mM}$ acetylthiocholine iodide. Enzyme activity was expressed in $\mu$ moles AcSCh/h.mg of protein.

\section{Protein determination}

Protein was measured according to Bradford (1976) using bovine serum albumin as a standard.

\section{Statistical analysis}

To verify the homogeneity of variances, all data were submitted to a Levene test. As the variance of the data from each group were found to be equivalent, analysis was carried out using analysis of variance (three-way ANOVA) followed by the Tukey Kramer multiple comparisons test, and significance was set at a level of $95 \%(p<0.05)$. All data were expressed as mean \pm S.D.

\section{Results}

We found that NTPDase and AChE activities, as measured from the S1 fraction of whole brain, of silver catfish were altered only after $24 \mathrm{~h}$ of exposure to the experimental conditions. Specifically, we found a significant interaction between dissolved oxygen and ammonia levels on ATP and ADP hydrolysis as well as AChE activity $(\mathrm{p}<0.05)$.

Statistical analysis using a Tukey-Kramer test revealed a significant increase $(100 \%)$ in ATP hydrolysis in fish exposed to high $\mathrm{NH}_{3}$ and low $\mathrm{O}_{2}$ levels (group D) over the control group (A) after $24 \mathrm{~h}$ of exposure (Fig. 1). Additionally, post hoc analysis revealed that ADP hydrolysis increased 119\% in group D compared to the control group after $24 \mathrm{~h}$ (Fig. 2). Two treatments in particular produced a significant increase in ADP hydrolysis in the whole brain, including high oxygen/ high ammonia and low oxygen/high ammonia, when compared to the control group.

AChE activity increased 34\% in group D relative to the 
control group after $24 \mathrm{~h}$ exposure. In addition, fish exposed to high $\mathrm{NH}_{3}$ and high $\mathrm{O}_{2}$ levels (group $\mathrm{C}$ ) showed a 39\% increase in AChE activity over control after 24 h exposure (Fig. 3). Based on the results obtained, 6 h exposure to low dissolved oxygen or high ammonia levels did not alter enzyme activities.

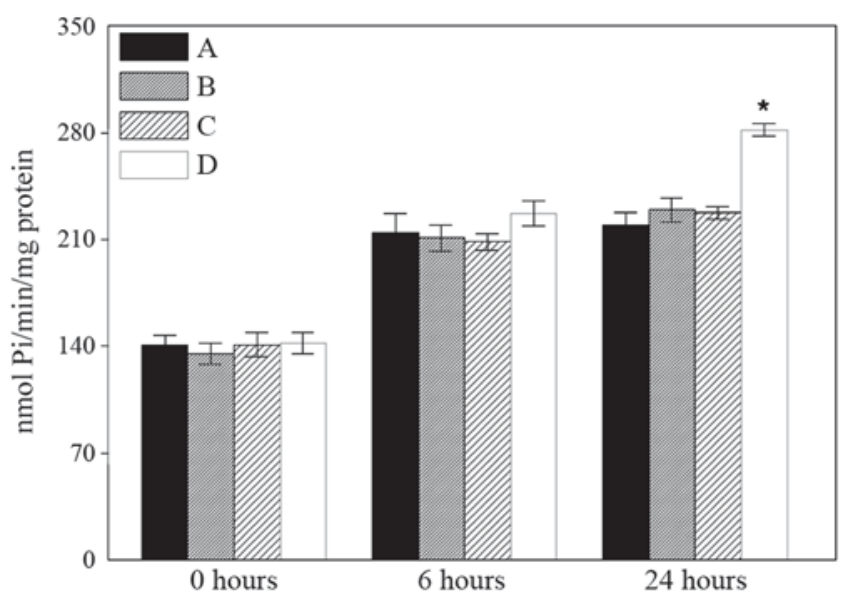

Fig. 1. ATP hydrolysis in supernatant of whole brain of silver catfish.

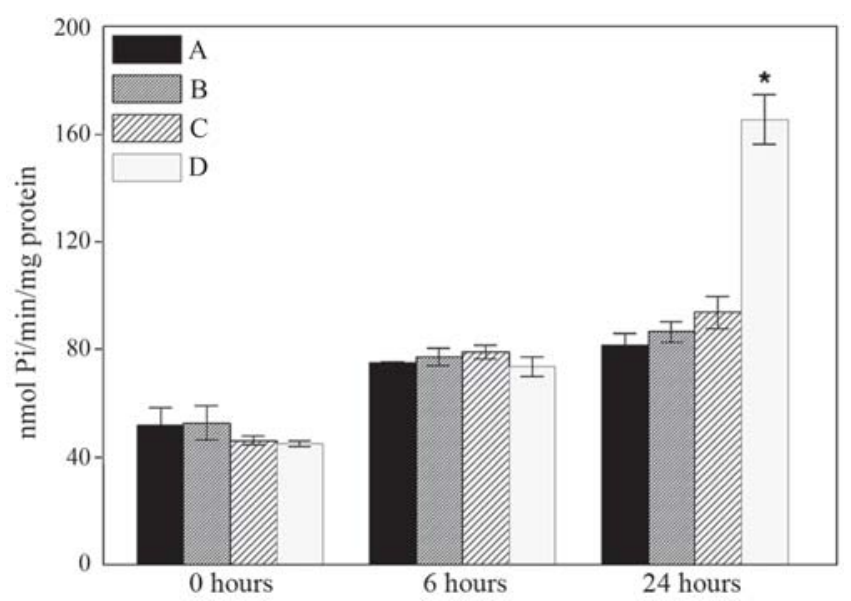

Fig. 2. ADP hydrolysis in supernatant of whole brain of silver catfish.

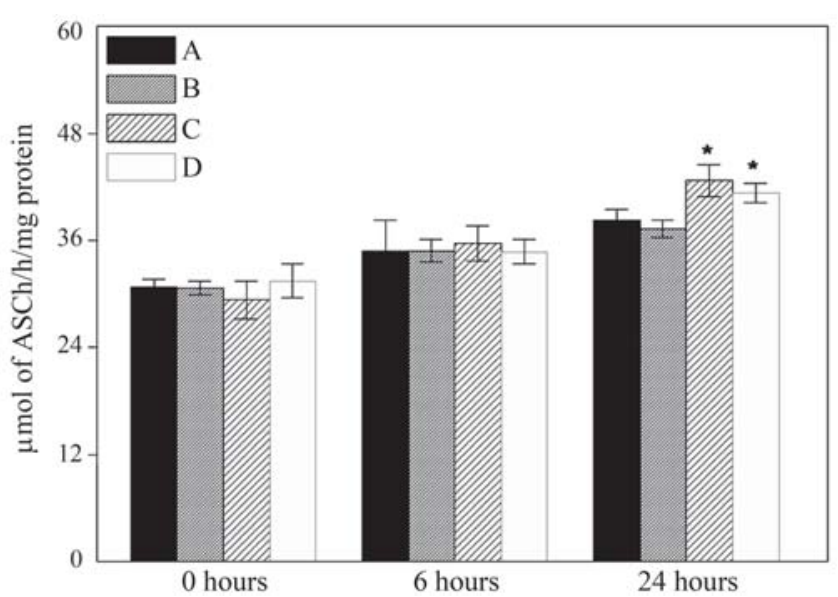

Fig. 3. AChE activity in supernatant of whole brain of silver catfish.

\section{Discussion}

In the present study, high exogenous un-ionized ammonia levels $\left(\mathrm{NH}_{3}\right)$ combined with various oxygen saturation levels altered NTPDase and AChE activities after $24 \mathrm{~h}$ of exposure. Several experiments have reported that ammonia interacts with oxygen, becoming highly toxic at low oxygen levels. At the cellular level, ammonia can interfere with energy metabolism through impairment of the tricarboxylic acid cycle in fish (Arillo et al., 1981), thus affecting brain energy metabolism. This outcome supports the hypothesis that ammonia is more toxic at low oxygen saturation levels.

The extracellular nucleotides ATP and ADP are involved in important physiological mechanisms, such as hemostasis and thromboregulation (Sarkis et al., 1986; Enjyoji et al., 1999) as well as neurotransmission (Edwards et al., 1992). The known ability of NTPDase to hydrolyze ATP and ADP nucleotides makes it a fundamental constituent in cellular metabolism (Schetinger et al., 2001). In this study, ATP and ADP hydrolysis were enhanced in the group exposed to low dissolved oxygen plus high $\mathrm{NH}_{3}$ levels for $24 \mathrm{~h}$. This finding supports the hypothesis that ammonia is more toxic at low oxygen saturation levels.

AChE activity was increased after $24 \mathrm{~h}$ exposure in both the high dissolved oxygen plus high $\mathrm{NH}_{3}$ group $\mathrm{C}$ and the low dissolved oxygen plus high $\mathrm{NH}_{3}$ group $\mathrm{D}$ compared to the control group. For the group that received low dissolved oxygen plus high $\mathrm{NH}_{3}$ (group D), the change in NTPDase activity paralleled the change in AChE activity. This finding may be due to an interaction between low oxygen saturation and ammonia, resulting in intensified ammonia toxicity. Foss et al. (2007) determined that growth in juvenile turbots was not impaired when elevated ammonia levels were introduced in water supersaturated with oxygen, suggesting that hyperoxic conditions increase tolerance to an environment high in ammonia. This previous finding is supported by our finding of increased AChE activities in the high $\mathrm{O}_{2} /$ high $\mathrm{NH}_{3}$ fish compared with the low $\mathrm{O}_{2}$ /high $\mathrm{NH}_{3}$ fish (Fig. 3).

Importantly, ammonia can impair the tricarboxylic acid cycle in fish, which is responsible for acetyl-CoA oxidation to $\mathrm{CO}_{2}$, so increased $\mathrm{NH}_{3}$ can lead to a build-up of acetyl-CoA. In this study, $24 \mathrm{~h}$ of exposure to low oxygen levels (hypoxia) plus high ammonia levels resulted in alterations of enzyme activities. Additionally, the increase in NTPDase activity was significantly greater that the increase in AChE activity. This differential increase in activities may be due to the increase of ammonia toxicity caused by an interaction with low oxygen saturation, as well as hypoxic events. It is known that hypoxic events lead to vasodilatation, which is promoted by adenosine, leading to increased blood flow and therefore substrate availability (Berne et al., 1983; Collis, 1989).

Our findings corroborate several studies reporting that high ammonia levels at normal or low oxygen saturation increase ammonia toxicity (Wee et al., 2007; Foss et al., 2007; Ronan et al., 2007). Specifically, our findings demonstrate that the interaction between low oxygen saturation and high 
$\mathrm{NH}_{3}$ levels results in increased NTPDase and AChE activities in whole brain of silver catfish after $24 \mathrm{~h}$ of exposure.

\section{Acknowledgements}

This study was supported by CNPq, FAPERGS, CAPES, Universidade Federal de Santa Maria, and FINEP research grant "Rede Instituto Brasileiro de Neurociência (IBN-Net)".

\section{Literature Cited}

Alabaster, J. S. \& R. Lloyd. 1980. Water quality criteria for freshwater fish. 2nd edition. London, Butterworths, 283p.

Arillo, A., C. Margiocco, F. Melodia, P. Mensi \& G. Schenone. 1981. Ammonia toxicity mechanisms in fish: studies on rainbow trout (Salmo gairdneri Rich). Ecotoxicology and Environmental Safety, 5: 316-325.

Atwood, H. L., J. R. Tomasso, P. J. Ronan, B. A. Barton \& K. J. Renner. 2000. Brain monoamine concentrations as predictors of growth inhibition in channel catfish exposed to ammonia. Journal of Aquatic Animal Health, 12: 69-73.

Barcellos, L. J. G., L. C. Kruetz, R. M. Quevedo, I. Fioreze, A. B. S. Cericato \& F. Ritter. 2004. Nursey rearing of jundiá, Rhamdia quelen (Quoy \& Gaimard) in cages: cage types, stocking density and stress response to confinement. Aquaculture, 232: 383-394.

Berne, R. M., R. M. Knabb, S. W. Ely \& R. Rubio. 1983. Adenosine in the local regulation of blood flow: a brief overview. Federation Proceedings, 42: 3136-3142.

Boyd, C. E. \& C. S. Tucker. 1992. Water quality and pond soil analyses for Aquaculture. Auburn, Alabama, Auburn University, 183p.

Bradford, M. M. 1976. A rapid and sensitive method for the quantification of microgram quantities of protein utilizing the principle of protein-dye binding. Analytical Biochemistry, 72: 218-254.

Brake, A. J. \& D. Julius. 1996. Signaling by extracellular nucleotides. Annual Review of Cell and Developmental Biology, 12: 519-541.

Braun, N., R. L. Lima, B. Moraes, V. L. Loro \& B. Baldisserotto. 2006. Survival, growth and biochemical parameters of silver catfish, Rhamdia quelen (Quoy \& Gaimard, 1824), juveniles exposed to different oxygen levels. Aquaculture Research, 37: 1524-1531.

Bretaud, S., J. P. Toutant \& P. Saglio. 2000. Effects of carbofuran, diuron and nicosulfuron on acetylcholinesterase activity in goldfish (Carassius auratus). Ecotoxicology and Environmental Safety, 47(2): 117-124.

Burnstock, G. 1998. History of extracellular nucleotides and their receptors. Pp. 3-42. In: Turner, J. T., G. A. Weisman \& J. S. Fedan (Eds.). The P2 nucleotide receptors. Totowa, N.J., Humana Press, 440p.

Butterworth, R. F. 1998. Effects of hyperammonaemia on brain function. Journal of Inherited Metabolic Disease, 21(1): 6-20.

Collis, M. G. 1989. The vasodilator role of adenosine. Pharmacology \& Therapeutics, 41(1/2): 143-162.

Colt, J., K. Orwicz \& G. Bouck. 1991. Water quality considerations and criteria for high-density fish culture with supplemental oxygen. American Fisheries Society Symposium, 10: 372-385.

Cooper, A. J., J. M. McDonald, A. S. Gelbard, R. F. Gledhill \& T. E. Duffy. 1979. The metabolic fate of $13 N$-labeled ammonia in rat brain. The Journal of the Biological Chemistry, 254(12): 4982-4992.
Cooper, A. J. L. \& F. Plum. 1987. Biochemistry and physiology of brain ammonia. Physical Review, 67: 440-519.

Cunha, R. A. \& J. A. Ribeiro. 2000. ATP as a presynaptic modulator. Life Sciences, 68: 119-137.

Dahm, K. C. S., C. Rückert, E. M. Tonial \& C. D. Bonan. 2006. In vitro exposure of heavy metals on nucleotidase and cholinesterase activities from the digestive gland of Helix aspersa. Comparative Biochemistry and Physiology Part C, 143: 316-320.

Edwards, F. A., A. J. Gibb \& D. Colquhoun. 1992. ATP receptormediated synaptic currents in the central nervous system. Nature, 359: 144-147.

Ellman, G. L., D. K. Courtney \& R. M. Andres. 1961. A new and rapid colorimetric determination of acetylcholinesterase activity. Biochemical Pharmacology, 7: 88-95.

Enjyoji, K., J. Sevigny, Y. Lin, P. S. Frenette, P. D. Christie, J. S. Esch, M. Imai, J. M. Edelberg, H. Rayburn, M. Lech, D. L. Beeler, E. Csizmadia, D. Wagner, S. C. Robson \& R. D. Rosenberg. 1999. Targeted disruption of CD39/ATP diphosphohydrolase results in disordered hemostasis and thromboregulation. Nature Medicine, 5: 1010-1017.

Felipo, V. \& R. F. Butterworth. 2002. Neurobiology of ammonia. Progress in Neurobiology, 67(4): 259-279.

Fernández-Veja, C., E. Sancho, M. D. Ferrando \& E. Andreu. 2002. Thiobencarb-induced changes in acetylcholinesterase activity of the fish Anguilla anguilla. Pesticide Biochemistry and Physiology, 72: 55-63.

Fields, R. D. \& G. Burnstock. 2006. Purinergic signaling in neuronglia interactions. Nature Reviews Neuroscience, 7: 423-436.

Foss, A., A. K. Imsland, B. Roth, E. Schram \& S. O. Stefansson. 2007. Interactive effects of oxygen saturation and ammonia on growth and blood physiology in juvenile turbot. Aquaculture, 271: 244-251.

Fredholm, B. B. 1995. Purinoreceptors in the nervous system. Pharmacology \& Toxicology, 76: 228-239.

Fredholm, B. B., A. P. Ijzerman, K. A. Jacobson, K. N. Klotz \& J. Linden. 2001. International Union of Pharmacology: XXV. Nomenclature and classification of adenosine receptors. Pharmacological Reviews, 53: 527-552.

Gayle, R. B., C. R. Maliszewski, S. C. Gimpel, M. A. Schoenborn, R. G. Caspary, C. Richards, K. Brasel, V. Price, J. H. Drosopoulos, N. Islam, T. N. Alyoncheva, M. J. Broekman \& A. J. Marcus. 1998. Inhibition of platelet function by recombinant soluble ecto-ADPase/CD39. The Journal of Clinical Investigation, 101: 1851-1859.

Gonçalves, P. P. \& V. S. Silva. 2007. Does neurotransmission impairment accompany aluminum neurotoxicity? Journal of Inorganic Biochemistry, 101: 1291-1338.

Habig, C. \& R. T. Di Giulio. 1991. Biochemical characteristics of cholinesterases in aquatic organisms. Pp. 20-30. In: Mineau, P. (Ed.). Cholinesterase-Inhibiting Insecticides. Their Impact on Wildlife and the Environment. Amsterdam, Elsevier, 348p.

Le-Ruyet, P., J. Galland, A. Le Roux \& H. Chartois. 1997. Chronic ammonia toxicity in juvenile turbot Scophthalmus maximus. Aquaculture, 154: 155-171.

Lutz, P. L. \& R. Reiners. 1997. Survival of energy failure in the anoxic frog brain: delayed release of glutamate. The Journal of Experimental Biology, 200: 2913-2917.

Marcus, A. J., M. J. Broekman, J. H. Drosopoulos, N. Islam, D. J. Pinsky, C. Sesti \& R. Levi. 2003. Metabolic control of excessive extracellular nucleotide accumulation by CD39/ecto-nucleotidase1: Implications for ischemic vascular diseases. The Journal of Pharmacology and Experimental Therapeutics, 305: 9-16. 
McKenzie, D. J., D. J. Randall, H. Lin \& S. Aota. 1993. Effects of changes in plasma $\mathrm{pH}, \mathrm{CO}_{2}$ and ammonia on ventilation in trout. Fish Physiology and Biochemistry, 10: 507-515.

Miron, D., M. Crestani, M. R. Schetinger, V. M. Morsch, B. Baldisserotto, M. A. Tierno, G. Moraes \& V. L. P. Vieira. 2005. Effects of the herbicides clomazone, quinclorac, and metsulfuron methyl on acetylcholinesterase activity in the silver catfish (Rhamdia quelen) (Heptapteridae). Ecotoxicology and Environmental Safety, 61: 398-403.

Miron, D. S., B. Moraes, A. G. Becker, M. Crestani, R. Spanevello, V. L. Loro \& B. Baldisserotto. 2008. Ammonia and pH effects on some metabolic parameters and gill histology of silver catfish, Rhamdia quelen (Heptapteridae). Aquaculture, 277: 192-196.

Moraes, B. S., V. L. Loro, L. Glusczak, A. Pretto, C. Menezes, E. Marchezan \& S. O. Machado. 2007. Effects of four rice herbicides on some metabolic and toxicology parameters of teleost fish (Leporinus obtusidens). Chemosphere, 68: 1597-1601.

Mubagwa, K. \& W. Flameng. 2001. Adenosine, adenosine receptors and myocardial protection: An updated overview. Review. Cardiovascular Research, 52: 25-39.

Parvez, S. \& S. Raisuddin. 2005. Protein carbonyls: novel biomarkers of exposure to oxidative stress-inducing pesticides in freshwater fish Channa punctata (Bloch). Environmental Toxicology and Pharmacology, 20: 112-117.

Piaia, R., C. R. Townsend \& B. Baldisserotto. 1999. Growth and survival of fingerlings of silver catfish exposed to different photoperiods. Aquaculture International, 7: 1-5.

Piper, R. G., I. B. McElwain, L. E. Orme, J. P. McCraren, L. G. Fowler \& J. R. Leonard. 1982. Fish hatchery management. United States Department of the Interior. Washington, D.C., Fish and Wildlife Service, 517p.

Rico, E. P., D. B. Rosemberg, M. R. Senger, M. B. Arizi, R. D. Dias, A. A. Souto, M. R. Bogo \& C. D. Bonan. 2008. Ethanol and acetaldehyde alter NTPDase and 5'-nucleotidase from zebrafish brain membranes. Neurochemistry International, 52: 290-296.

Robson, S. C., J. Sévgny \& H. Zimmerman. 2006. The E-NTPDase family of ectonucleotidases: Structure function relationships and pathophysiology significance. Purinergic Signaling, 2: 409430.

Rocha, J. B. T., T. Emmanuelli \& M. E. Pereira. 1993. Effects of early undernutrition on kinetic parameters of brain acetylcholinesterase from adult rats. Acta Neurobiologiae Experimentalis, 53: 431-437.

Roex, E. W. M., R. Keijzers \& C. A. M. van Gestel. 2003. Acetylcholinesterase inhibition and increased food consumption rate in the zebrafish, Danio rerio, after chronic exposure to parathion. Aquatic Toxicology, 64: 451-460.

Ronan, P. J., M. P. Gaikowski, S. J. Hamilton, K. J. Buhl \& C. H. Summers. 2007. Ammonia causes decreased brain monoamines in fathead minnows (Pimephales promelas). Brain Research, 1147: 184-191.

Saglio, P. \& S. Trijasse. 1998. Behavioral responses to atrazine and diuron in goldfish. Archives of Environmental Contamination and Toxicology, 35: 484-491.

Sarkis, J. J. F., J. A. Guimarães \& J. M. C. Ribeiro. 1986. Salivary apyrase of Rhodnius prolixus: kinetics and purification. Biochemical Journal, 233: 885-891.

Schetinger, M. R., N. M. Porto, M. B. Moretto, V. M. Morsch, J. B. T. Rocha, V. Vieira, F. Moro, R. T. Neis, S. Bittencourt, H. G. Bonacorso \& N. Zanatta. 2000. New benzodiazepines alter acetylcholinesterase and ATPDase activities. Neurochemical Research, 25: 949-955.
Schetinger, M. R. C., C. D. Bonan, V. M. Morsch, D. Bohrer, L. M. Valentim \& S. R. Rodrigues. 1999. Effects of aluminum sulfate on delta-aminolevulinate dehydratase from kidney, brain, and liver of adult mice. Brazilian Journal of Medicine and Biological Research, 32: 761-766.

Schetinger, M. R. C., V. L. P. Vieira, V. M. Morsch \& D. Balz. 2001. ATP and ADP hydrolysis in fish, chicken and rat synaptosomes. Comparative Biochemistry and Physiology Part B, 128: 731741.

Schweibert, E. M. \& A. Zsembery. 2003. Extracellular ATP as a signaling molecule for epithelial cells. Biochimica \& Biophysica Acta, 1615: 7-32.

Smart, G. R. 1976. The effect of ammonia exposure on gill structure of the reinbow trout Salmo gairdneri. Journal of Fish Biology, 8: 471-475.

Thurston, R. V., R. J. Russo, R. J. Luedtke, C. E. Smith, E. L. Meyn, C. Chakoumalos, K. C. Wang \& C. J. D. Brown. 1984. Chronic toxicity of ammonia to rainbow trout. Transactions of the American Fisheries Society, 113: 56-73.

Viseck, W. J. 1968. Some aspects of ammonia toxicity in animal cells. Journal of Dairy Science, 51: 286-295.

Wajsbrot, N., A. Gasith, M. D. Krom \& D. M. Popper. 1991. Acute toxicity of ammonia to juvenile gilthead seabream Sparus aurata under reduced oxygen levels. Aquaculture, 92: 277-288.

Wee, N. L. J., Y. Y. M. Tng, H. T. Cheng, S. M. L. Lee, S. F. Chew \& Y. K. Ip. 2007. Ammonia toxicity and tolerance in the brain of the African sharptooth catfish, Clarias gariepinus. Aquatic Toxicology, 82: 204-213.

Wood, C. M. 2001. Toxic responses of the gill. Pp.1-89. In: Schlenk, D. \& W. H. Benson (Eds.). Target Organ Toxicity in Marine and Freshwater Teleosts. Volume 1 - Organs. London, Taylor \& Francis, 372p.

Zimmerman, H. 1992. 5'-nucleotidase-molecular structure and functional aspects. The Biochemical Journal, 285: 345-365.

Accepted September 12, 2009

Published December 18, 2009 